\title{
Records of the Redpath Chautauqua
}

\author{
ROBERTA. M c COWN
}

Circuit or "tent" Chautauqua had its beginnings in the lyceum movement, which had started in Massachusetts as early as 1826, and in the Chautauqua assemblies held at Lake Chautauqua, New York. beginning in 1874. The purpose of the lyceum movement was selfimprovement by lectures and discussions on literary, scientific, and moral topics. Lyceums soon spread to all of the New England states, New York, and eventually to the southern and western states. After the Civil War, commercial lecture bureaus were founded, among them the Redpath Lyceum Bureau of James C. Redpath in 1868. In the next ten years such famous names as Susan B. Anthony, P. T. Barnum. Henry Ward Beecher, James G. Blaine, Wilkie Collins, Mark Twain. and Ralph Waldo Emerson were represented by the Redpath Bureau. Lyceums continued to exist into the twentieth century, although by 1925 they were found for the most part only in small towns, often in combination with musical programs.

In 1874 John H. Vincent, a Methodist clergyman, and Lewis Miller. an Akron, Ohio, businessman, decided to start a summer school to instruct Sunday school teachers in the organization, management, and teaching of Sunday schools. The first such summer school was held on the shore of Lake Chautauqua in the very western part of New York state in August, 1874. The assembly included not only instruction, but recreation on the Lake and lectures on other than religious topics. The first Chautauqua Assembly was like a summer camp. In later years. however, hotels, clubhouses, lecture halls, and permanent summer homes were built, and the Assembly assumed a permanent character. In 1879 the Chautauqua Normal School of Languages was founded. thus starting the Chautauqua Summer Schools. In the following years other new courses were introduced until Chautauqua became a sort of summer university. In 1901 a school of library training was begun at Chautauqua under the guidance of Melvil Dewey. Such distinguished scholars as the historian Herbert Baxter Adams and the economist 
Richard T: Ely lectured at the Chautauqua Assembly during the summer season. ${ }^{\text {I }}$

In 1878, Bishop Vincent established the Chautauqua Literary and Scientific Circle (C.L.S.C.), a home-study or correspondence course. The C.L.S.C. was a four-year reading course in the humanities, sciences, theology, and social studies. Seven thousand persons enrolled in the reading course in the first year of its existence. People would then join together in groups or circles to discuss the books that they were reading. By 1885 Iowa had more than one hundred circles, with thirty of them in Des Moines. ${ }^{2}$

Traveling to the Chautauqua Assembly in New York was not possible for everyone who wanted to attend such a summer school. Consequently, assemblies similar to the one at Lake Chautauqua appeared in various parts of the United States and called themselves daughter Chautauquas or independent assemblies. These new assemblies usually had their own "campgrounds" and preferably were located near a lake or wooded area with camping facilities. Independent assemblies arose in such places as Petoskey, Michigan; Sandusky, Ohio; Lake Bluff, Illinois; Ottawa, Kansas; and in 1876, Clear Lake, Iowa. The Clear Lake Camp Meeting and Assembly Chautauqua was the first assembly to be established in the state of Iowa. ${ }^{3}$ The Independents were not really summer schools, but people came to attend lectures, musical events, plays, and non-denominational religious exercises.

At this point a connection arose between independent assemblies and the lyceum. The managers of the daughter Chautauquas were eager to attract "big name" performers for their summer assemblies. The lyceum bureaus could provide those performers. However, the lyceum bureaus ran into difficulties supplying the far-flung assemblies. Often the assemblies were scheduled at the same time of the summer, causing conflicts over the scheduling. Because these assemblies were located so far apart geographically, the talent had to make long railroad trips between performances. Such trips meant many days when the talent could not perform (open dates). There was great competition

1 For an introduction to the New York Chautauqua Assembly see Jesse Lyman Hurlburt, The Story of Chautauqua (New York: G. P. Putnam's Sons, 1921); Jeffrey Simpson, "Utopia by the Lake," American Heritage, 23 (August, 1972), pp. 76-88; and Robert Louis Utlant, "The Role of the Chautauqua Movement in the Shaping of Progressive Thought in America at the End of the Nineteenth Century" (Ph.D. dissertation, University of Minnesota, 1972).

2 See Joseph E. Gould, The Chautauqua Movement, An Episode in the Continuing American Revolution (New York: State University of New York, 1961), p. 9.

3 See J. Francis Kee, "History of the Clear Lake, Iowa, Chautauqua" (M.A. thesis, The University of Iowa, 1938). 
among assemblies for the same performers and thus high costs for the daughter Chautauquas.

Keith Vawter was the man who attempted a solution to this problem of the independent assemblies, and in the process he invented tent or circuit Chautauqua. ${ }^{4}$ In the 1890's Vawter, a native Iowan, was working in a book store in Des Moines. At the same time he aided Professor Edward Amherst Ott of the speech department of Drake University in obtaining lecture talent for the Des Moines Lyceum. Ott. himself, was quite a famous lecturer on the subject of heredity versus environment. In 1901, Vawter purchased a one-third interest in the Redpath Lyceum Bureau and became the Redpath agent in Chicago for a few years until he moved his operations to Cedar Rapids. In the summer of 1904, Vawter launched the first Chautauqua circuit. Vawter proposed to group a number of towns with independent assemblies and some other towns in a circuit (lecturers would move on a specified course from town to town) and each town would have the same uniform program of talent. In this way, the lecturers would work full time, open dates would be eliminated, talent costs would be reduced by the use of long-time contracts, and railroad trips would be shorter. Fifteen towns in Iowa and Nebraska signed contracts for Vawter to provide talent for their Chautauquas in the summer of 1904. Vawter's venture lost money, but he determined to try again after improving the circuit idea.

In 1907 Vawter ran a circuit of thirty-three towns. According to the contract, Vawter furnished all of the talent, tents, advertising, and work crews, and the local citizens handled the advance sale of tickets. In the following years, Vawter made improvements in his circuit system. In 1909 he started the seven-day Chautauqua. A tent was set up in a new town on a Monday morning, for example, and the Chautauqua was ready for business on Monday afternoon. The last program was on Sunday, after which the tent was taken down, put into a railroad baggage car and moved to another town. The year 1910 saw the introduction of the final sophistication in program arrangement. Each performer or group was assigned to a definite day on the program and always performed in that sequence throughout the summer season. Thus, first-day talent remained first-day talent all season long. The same was true for second-day talent and so on for the seven groups of talent. The tent remained in a town for a whole week under

4 A good short introduction to circuit Chautauqua is Harrison John Thornton. "Chautauqua in Iowa," Iowa Journal of History and Politics, 50 (April, 1952). pp. 97-122. 
the direction of a superintendent who had charge of all the programs in that town, but the first-day talent moved at once to another town and opened another first day. Eventually there were also five-day and three-day circuits, but these were usually not Redpath circuits.

The basic business arrangement for Chautauqua involved the "contract" and a system of "guarantors." Under this method a local Chautauqua committee signed a contract pledging its cooperation in the sale of tickets for next summer's Chautauqua and also guaranteeing payment in the event of a deficit. Members of the committee were usually prominent businessmen of each community. Thus, this committee was responsible for promoting season ticket sales and thereby ensuring the success of the Chautauqua. If the committee failed in its ticket sales, they would be the losers financially. Some townspeople objected to Vawter's contract system. They remembered that the circus and the traveling theatre groups came to town without a contract. Why did Chautauqua need a binding agreement? Vawter believed that Chautauqua was an "educational institution with ideals" first and a business enterprise second. In a letter to a Chautauqua superintendent in Missouri, Vawter wrote:

Over twenty years ago I told some friends that a Chautauqua would be a success just as long as it was of sufficient importance in the community that a group of men and women would do a lot of hard work for the good of the Community. Chautauqua never has [been], and never can be, self-supporting from a purely business standpoint. 5

Most leaders of circuit Chautauqua seemed honestly to believe in the moral and educational nature of Chautauqua.

Redpath Chautauquas were much more than just Keith Vawter's headquarters in Cedar Rapids, Iowa. The Redpath Lyceum Bureau had offices in many other American cities, including White Plains, New York, Columbus, Ohio, Chicago, and Kansas City, and these offices also became involved in circuit Chautauqua. Vawter's territory was roughly Iowa, Minnesota, the Dakotas, Nebraska, and Missouri. The Chicago office was run by another Iowan and former Vawter employee, Harry P. Harrison. Under the name "Redpath-Chicago," Harrison launched a major Chautauqua circuit in 1912. Harrison's territory was Illinois, Indiana, Ohio, Michigan, Kentucky, Tennessee, and the Gulf states. His circuits started in the South in the spring and worked northward toward Michigan in the fall. Harry Harrison was successful in introducing classical music, grand opera, and Shakespeare

5 Keith Vawter to C. B. Wait, August 23, 1926, Keith Vawter Papers in the Redpath Chautauqua Collection, The University of Iowa Libraries, Iowa City, Iowa. 
to Chautauqua audiences. ${ }^{6}$ Charles F. Horner helped Keith Vawter organize the circuit Chautauqua system. In 1912 Horner established in Kansas City the "Western Redpath Chautauqua" or "Redpath-Horner." His territory was Missouri, Arkansas, Texas, Oklahoma, Kansas, Nebraska, Wyoming, Colorado, and South Dakota. Horner was notable for encouraging amateurs to enter Chautauqua work. He even set up his own school, The Horner Institute of Fine Arts, to train talent. ${ }^{7}$ Of course, in addition to Redpath Chautauqua, other companies operated circuits. Besides Vawter at Cedar Rapids there were at least three other companies in Iowa alone: Acme Chautauquas in Des Moines, Jones Chautauqua System in Perry, and Travers-Newton in Des Moines.

When the train carrying the first-day talent and the baggage arrived in a town early in the morning, there was usually a parade to the Chautauqua grounds. Then the crew (college boys known as the "anvil chorus") set up the huge brown Chautauqua tent. The standard tent measured about 125 feet by 175 feet. $^{8}$ After the tent was set up, wooden benches or folding chairs were set up and a stage or platform was erected. The first two rows of seats were reserved for older people and people with hearing difficulties. In the event of a large crowd, the sides of the tents could be raised and people could sit outside. However, a large canvas wall encircled the area of the tent to keep out intruders.

Violent rain storms, heavy wind, and tornadoes were always the great fear of Chautauqua superintendents. Charles Horner devised a method to keep an eye on the weather: "Moreover we would secure a weather committee in each city. The men of it were old-timers accustomed to scanning the skies, and they were on hand to warn us if the weather was too threatening." A tornado once did destroy a Redpath-Vawter tent in Woodbine, Iowa, but fortunately the people were already out of the tent.

Children had their own special program called "junior Chautauqua." This innovation to keep the children busy also came from the inventive mind of Charles Horner. A "junior girl" took charge of the children for the seven days that Chautauqua was in town. She told

\footnotetext{
6 See Harry P. Harrison, Culture Under Canvas; The Story of Tent Chautauqua (New York: Hastings House, 1958).

7 See Charles F. Horner, Strike the Tents, The Story of Chautauqua (Philadelphia: Dorrance \& Company, 1954).

8 Hugh A. Orchard, Fifty Years of Chautauqua, Its Beginnings, Its Development, Its Message and Its Life (Cedar Rapids, Iowa: The Torch Press, 1923), p. 239. Orchard's book is now old and not very objective, but it is a real encyclopedia of Chautauqua and of great value to the scholar.

9 Horner, Strike the Tents, p. 71.
} 
them stories; organized games, parties, stunts, folk dances, and athletics; set up a "junior town organization" with a mayor, town clerk, etc.; and finally directed a pageant which was produced for admiring parents.

The program, of course, was what the Chautauqua was all about. "Talent" included musicians, lecturers, humorists, actors, interpretive readers, magicians, and others. Some of the talent worked the year around as entertainers: lyceum in the winter and tent Chautauqua in the summer. For others, such as authors, teachers, clergymen, and politicians, Chautauqua provided a little extra salary in the summertime. Some Chautauqua circuits did offer real educational opportunities. In 1915 Harry Harrison presented Alice Neilson, the grand opera star, on his major circuit. Harrison also introduced dramatic productions acted by such talented groups as the Ben Greet Players. The sculptor Lorado Taft set up his studio on the Chautauqua stage and demonstrated to audiences his techniques of creating a piece of statuary. Taft told Gay MacLaren his purpose in working for Chautauqua: "My main reason for lecturing is that I may awaken public interest in having community art galleries, that I may interest young people in becoming sculptors." 10

About half of a Chautauqua program consisted of music. There were Swiss bell ringers, orchestras, glee clubs, string quartets, grand opera stars such as Madame Schumann-Heink, oratorio artists, bands (Bohumir Kryl's Bohemian Band was a favorite), and male quartets. One of the most famous male quartets was made up of four farm boys from Charles City, Iowa, the Weatherwax Brothers.

However, the Chautauqua program really centered on the lecturer, the "backbone of Chautauqua." Gay MacLaren believed that there were three types of Chautauqua lectures: "the Challenge lecture, the Informative lecture, and the Inspirational lecture."1l Charles Horner wrote that Chautauqua lecturers had to be inspirational.

It was the quality in the speaker's life and demeanor and words that made men and women want to freshen their ambitions, to aspire a little higher, to become better neighbors and friends, to clean up the town a bit, to kiss the children when they returned to their homes, and perhaps pray a little more.12

All in all, religion, temperance, and politics were the most popular subjects. Some of the popular Chautauqua lecturers included Maud Ballington Booth, Frank W. Gunsaulaus, Judge Ben B. Lindsey, John

10 Gay MacLaren, Morally We Roll Along (Boston: Little, Brown and Company, 1938), p. 148. Miss MacLaren's book tells the Chautauqua story from the point of view of the talent and is a delightful book.

11 MacLaren, Morally We Roll Along, p. 173.

12 Horner, Strike the Tents, p. 39. 
T. McCutcheon, Opie Read, Lincoln Steffens, Ida Tarbell, and Francis J. Heney.

Politicians found that Chautauqua was a way to get paid for campaigning. Many ambitious officeholders realized that the Chautauqua platform gave out-of-state exposure in those days before radio and television. Warren G. Harding was one of the popular Chautauqua speakers, a headline attraction. Tent Chautauqua must certainly have been a factor in the increased political prestige of the former Ohio newspaper editor. Many Iowa politicians took advantage of the summer circuits: Smith W. Brookhart, Albert B. Cummins, Jonathan P. Dolliver, Leslie M. Shaw, and William S. Kenyon. Another headliner was Senator Robert M. LaFollette. The Senator's subject was often "Special Privilege" and he gave his listeners their money's worth. "One Redpath superintendent, when asked what 'Fighting Bob' talked about, said, 'About four hours. The first two hours the farmers wanted to rush to Washington and shoot Speaker Joe Cannon. After that they were for Cannon and wanted to shoot LaFollette." "13

William Jennings Bryan was perhaps the most famous Chautauqua lecturer. He once gave fifty lectures in twenty-eight days. Towns asked for him over and over again. He appeared in Clarinda, Iowa, seven times between 1897 and 1922.14 One young platform manager recorded this memory of Bryan:

I remember one blistering hot afternoon in a small Iowa town when Bryan was on the platform, and the orator was drenched with perspiration. He stopped in the middle of one of his rounded periods, dipped both hands into a large pitcher of ice water that stood on the table before him, and came up with two handfuls of crushed ice, which he held to his throbbing bald head for a minute or two. There was no laughter; we all felt sympathetic towards the old man.15

Marian Scott, another Chautauqua performer, wrote that talent needed "a hardy physique and a strongly controlled mental equipment" to endure the daily grind of a tent circuit. ${ }^{16}$ The life of the Chautauqua performer may have appeared glamorous, but there were many difficulties to be endured-insects in the dressing room, the heat of the tents, missed train connections, bad hotels, "greasy spoon" restaurants, few laundry facilities, and constant travel. Of course, most of the performers enjoyed such a peripatetic life and stayed in Chautauqua or

13 Harrison, Culture Under Canvas, p. 120.

14 Thornton, "Chautauqua in Iowa," pp. 17 and 19.

15 Frank Luther Mott, Time Enough, Essays in Autobtography (Chapel Hill: The University of North Carolina Press, 1962), pp. 93-94.

16 Marian Scott, Chautauqua Caravan (New York: D. Appleton-Century Company, 1939), p. 251. Miss Scott's book is another entertaining introduction to the world of tent Chautauqua. 
lyceum year after year. However, the tight booking may have driven away some of the best talent.

In the early years of this century, the Progressive Movement, a mood of political reform, began to sweep the United States. Bryan and LaFollette were part of this movement, along with such men as Joseph W. Folk of Missouri, Hiram Johnson of California, and Albert B. Cummins of Iowa. On the Chautauqua platform these men tried not to appear as politicians. Instead, they pointed out that railroad questions, tariff problems, and huge personal fortunes were not merely political questions but also involved morality. Thus, in a subtle way, the tent Chautauqua was used by Progressives to undermine their conservative political opponents, the "standpatters."

Many native Iowans or people with Iowa connections were engaged in tent Chautauqua as "talent," including such famous names as Billy Sunday and Herbert Hoover. Some less-well-known performers from Iowa were Adrian Newens, an entertainer and head of the speech department at Iowa State University; Ralph Dennis, who had been American vice-consul in Moscow during the Russian Revolution; Ben R. Vardaman, Des Moines advertising man who promoted community improvement; and the Reverend Charles Medbury, Des Moines minister, who spoke of his experiences as a chaplain in the Spanish-American War. Among the University of Iowa personnel active in Chautauqua were Earl Harper, director of the School of Fine Arts, and Walter A. Jessup, president of the University. Chautauqua was a nationwide movement, but Iowa was always its heart.

Circuit or tent Chautauqua began to expand and became a major influence about 1913, but World War I interrupted the circuits somewhat. In the years after the War (1920-1924), Chautauqua reached its peak of attendance. ${ }^{17}$ In 1920 there were twenty-one companies operating ninety-three circuits in the United States and Canada. Programs were presented in 8,580 towns to $35,449,750$ people. ${ }^{18}$ However, Marian Scott felt that Chautauqua changed after the War:

The old pleasant idea of Chautauqua being a big community enterprise, a big picnic was gone. It was regarded with a thoroughly professional attitude. We were a company of players who came in to give a show, and we were judged, condemned or acquitted entirely on the merit of our performances. The old friendly, personal note was gone. 19

Actually, the period of tent Chautauqua as a force in American life was fairly short.

17 Donald Linton Graham, "Circuit Chautauqua, A Middle Western Institution" (Ph.D. dissertation, The University of Iowa, 1953), p. 30. Graham's study is a scholarly full-length study of tent Chautauqua.

18 Horner, Strike the Tents, pp. 94 and 97.

19 Scott, Chautauqua Caravan, p. 250. 
While it lasted, Chautauqua did provide a number of bencfits to the American scene. Persons of national importance visited small towns, and in some cases these individuals had been dinner guests of townspeople. Chautauqua also provided employment for talent and crews. As many as six thousand college boys were employed as crew members each summer at the peak of Chautauqua. There can be little doubt that Chautauqua had a definite educational value and that it stimulated thought on social and political problems. The Chautauqua managers thought that tent Chautauqua taught townspeople to work together. In a spirt of "boosterism," townspeople would often attempt to clean up the town at Chautauqua times to present a neat appearance to visitors. Perhaps the greatest benefit of the traveling brown tents was that they served to break down isolation. A woman once told the author Ida Tarbell why Chautauqua appealed to her:

It is a great thing for us, particularly for us younger women with growing children. There are none of us in this town very rich. Most of us have to do all our work. We have little amusement, and almost never get away from home. The Chautauqua brings us an entire change. We plan for weeks before it. There is hardly a woman I know in town who has not her work so arranged, her pantry so full of food, that she can get to the meetings at halfpast two in the afternoon, and easily stay until five. She gets her work done up for Chautauqua week.20

The devotion to Chautauqua on the part of people in small towns sometimes produced results. Chautauqua speakers were definitely leaders in the fight against the liquor interests, and the circuits probably played a role in bringing about the adoption of nationwide prohibition.

Many reasons have been suggested for the decline of Chautauqua. Perhaps one of the main reasons for the end of the movement was the vast increase and oversupply in the number of Chautauquas. Every small town had to have its own Chautauqua for three days at least. As the number of Chautauquas increased, the balance between education and entertainment on the program shifted towards entertainment, and the quality decreased. A second reason was that America was changing its image: the small town, the little red schoolhouse, evangelistic Christianity, and William Jennings Bryan were losing their grip. The isolation of the middle border was over and Americans were introduced to rural free delivery, mail-order catalogues, hardsurface roads, automobiles and trucks, rural electrification, the telephone, radio, talking motion pictures, golf courses, and summer vacation trips. Keith Vawter wrote to his fellow Chautauqua managers: "I still insist that the radio did not materially affect lyceum and Chau-

20 Ida Tarbell, "A Little Look at the People," The Atlantic Monthly, 119 (May, 1917), p. 607. 


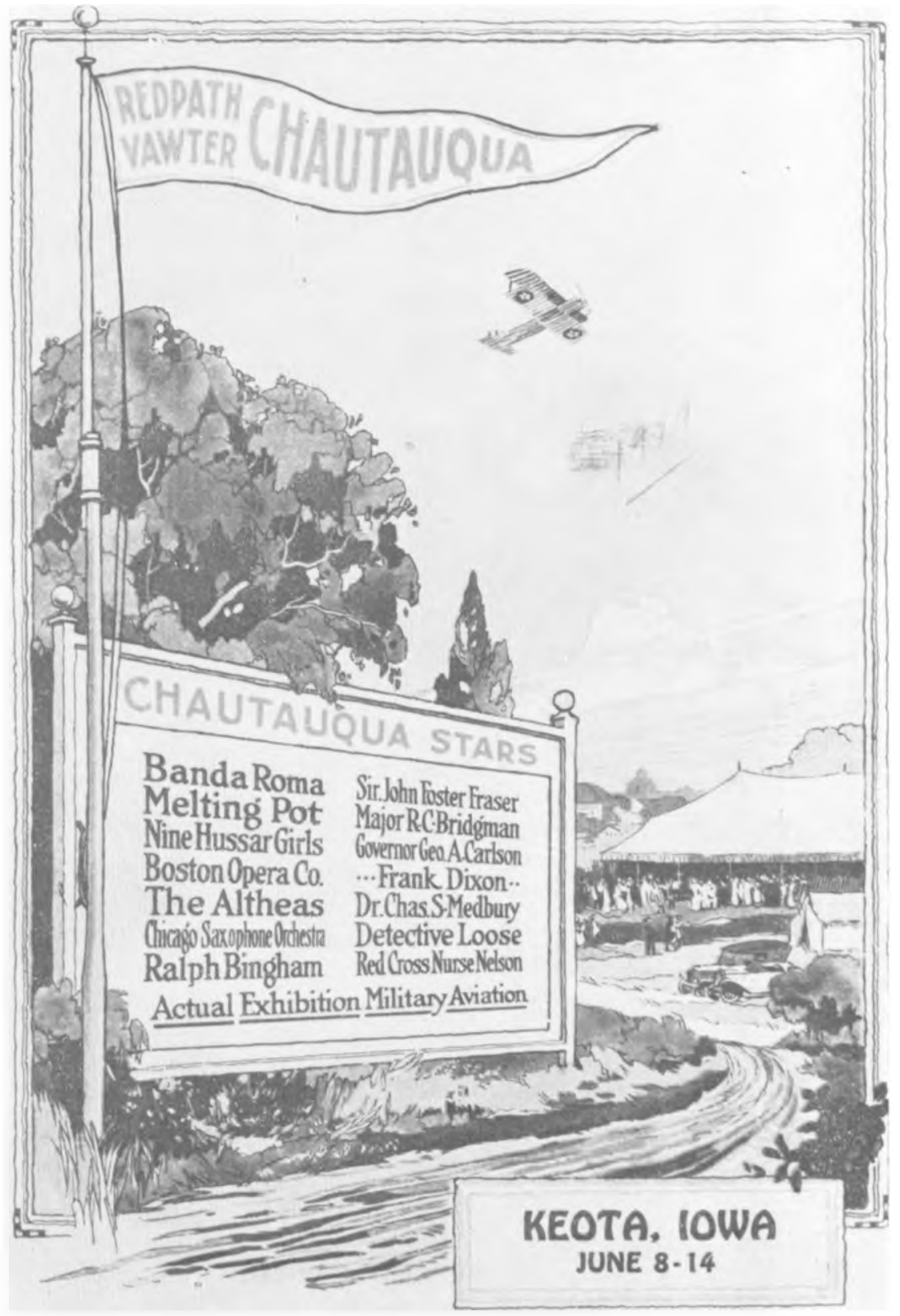

Front cover of a program for the Redpath-Vawter Chautaucua at Keota. Iowa. in June of 1919. Among the featured attractions were exhilsition flights by a military biplane and a talk on "The Romance of Flying" by a former pilot of the laifayette Escadrille. 

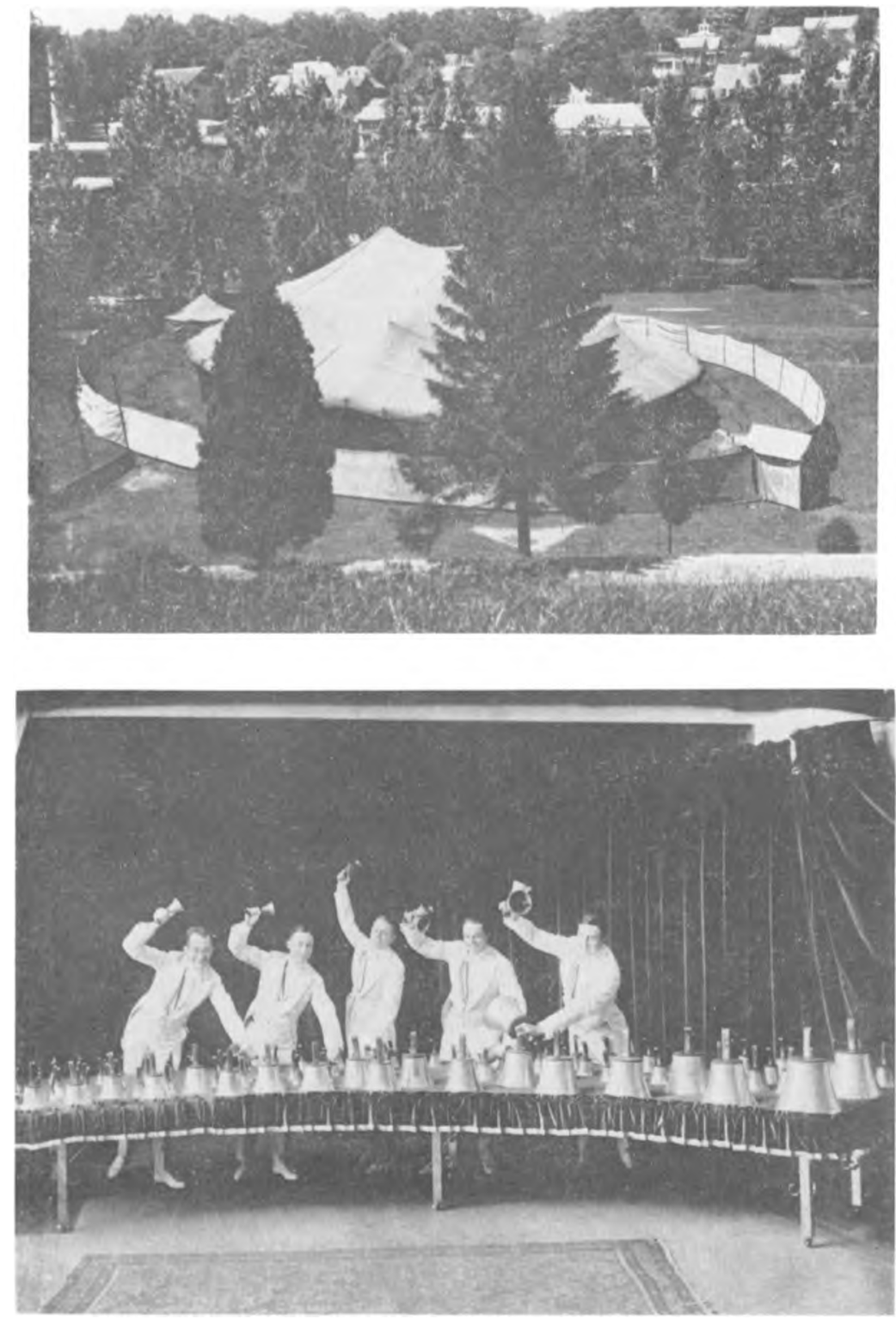

Top: A typical Chautaugua tent. The entrance is at the right. The small tent at the upper left was the summer home of the tent crew.

Bottom: Dunbar's Bell Ringers. They were a popular feature on the Chautauguat circuits. 
tauquas, but rather the advent of Country Clubs and Dancing Mothers." ${ }^{11}$ A third reason probably was economic: the rural areas felt hard times in the 1920 's and then after 1929 the Great Depression brought a final end to the circuits. Although an independent assembly Chautauqua lasted at Mediapolis, Iowa, until 1944, the final circuit folded its tents in 1932 and the splendor of tent Chautauqua was over.

The history of the huge Chautauqua collection in The University of Iowa Libraries is closely connected with the career of Harrison John Thornton, professor of history at the University from 1929 to 1952. One of Professor Thornton's scholarly interests was the lyceum and Chautauqua movements. In order to do research on lyceum and Chautauqua, Thornton set out to gather scholarly materials for the University Library for use by himself and his students. In 1938, after the death of Keith Vawter, Mrs. Vawter gave partial sets of a number of periodicals to the Library: The Lyceumite (1902-1907); Talent, a Magazine of Public Speaking (1890-1907); The Lyceumite and Talent (1907-1913), a merger of Talent and The Lyceumite; Lyceum Magazine (1913-1922), which continued The Lyceumite and Talent; and The Lyceum News (1911-1922). At the same time the estate of Mr. Vawter gave the personal papers of Keith Vawter to Professor Thornton for his own use. The Vawter papers consisted of correspondence, 1902-1936, and business records, 1891-1931. After the death of Professor Thornton the Vawter papers were transferred to the Library. Then in 1945 the magazine files of the International Lyceum Association came to The University of Iowa. This gift provided a number of new serial publications for use by researchers. The Library received such sets as the International Lyceum and Chautauqua Association Yearbooks (1911-1924); Lyceum Magazine and Leadership (1928-1929), a further continuation of The Lyceumite and Talent; The Platform World (1929-1933), a continuation of Lyceum Magazine and Talent; and Program (1934-1944).

In April, 1945, Professor Thornton received a letter from Stanley Pargellis, then Librarian of the Newberry Library in Chicago, describing a collection of three hundred transfer cases of Chautauqua and lyceum material at the Chicago office of the Redpath Bureau. Pargellis informed Thornton that the Redpath Bureau was willing to give the material to a library. Thornton wrote back immediately to Pargellis expressing a great interest in the collection. Harry Harrison, still head of the Redpath-Chicago office, agreed to let The University of Iowa Library have the office files of the Chicago office. In May, 1945, the Iowa State Board of Regents officially accepted the gift of Redpath

21 Keith Vawter to C. A. Peffer, Louis J. Alber, et al., January 17, 1929, Keith Vawter Papers. 
records as soon as the new library building was finished. However, in April, 1951, before the library was completed and dedicated, 13,500 pounds of Redpath material arrived in Iowa City. The packing cases from the Redpath-Chicago office contained business correspondence, letters to and from the talent, contracts, photographs, programs, handbills, tickets, posters, newspaper clippings, telegrams, route books, reports, and financial records (cash books, day books, journals, ledgers, cancelled checks, etc.).

The collection is presently divided into four series. The first series deals with talent and is arranged alphabetically (Brush, Edwin; Bryan, Charles W.; Bryan, E. B.; Bryan, William Jennings). The second series is filed by agents, and the third by business records. The fourth series is filed alphabetically by states and then by towns within states. A two-volume unpublished inventory for the collection has been prepared. The talent files contain correspondence and telegrams between performers on Chautauqua or lyceum and the Redpath Bureau, contracts, clippings, advertising brochures, and sometimes photographs. This material can be valuable for the scholar studying a particular person who worked for the Redpath Bureau. For instance, there are 161 letters covering the period 1921-1930 from the poet and speech professor Lew R. Sarett (1888-1954); 141 letters from the author and humorist Opie Read (1852-1939), covering the years 1910-1928; and 59 letters from the sculptor Lorado Taft spanning the years 1909-1929. Sometimes personal letters in the Chautauqua collection supplement materials already in the Library in other collections, as in the case of Maud Ballington Booth, "Little Mother of the Prisons."22 Letters from such people as Washington Gladden, David Starr Jordan, and John T. McCutcheon can be found in the collection.

The researcher interested in state and local history will find, in the Redpath records, material on Chautauqua and lyceum in many of the states and also the provinces of Canada as well as material dealing with particular towns. Illinois, Indiana, Iowa, Kentucky, and Michigan are particularly well represented in the collection. Material for the following towns or cities can be found in abundance: Fort Wayne and South Bend, Indiana; Iowa City, Iowa; Lexington, Kentucky; and Alma, Charlotte, Detroit, Flint, and Port Huron, Michigan.

Chautauqua bureaus other than the Redpath Bureau are represented to some extent in the collection. The Redpath Bureau often had dealings with other bureaus and also kept files on the activities of other Chautauquas. Other bureaus that are represented by material

22 See Susan Fulton Welty, "Maud Ballington Booth of the Volunteers of America," Books at Iowa, 13 (November, 1970), pp. 13-16. 
in the collection include Associated Chautauqua of America, the CoitAlber Chautauqua Company, Ellison-White Chautauqua System, Loar International Chautauquas, and the Swarthmore Chautauqua Association. ${ }^{23}$

Since 1951 the Library has continued to add more Chautauqua and lyceum material to the collection. In 1971 Bryan Horner, son of Charles Horner, sent a box containing correspondence from the early years of circuit Chautauqua. ${ }^{24}$ Early in 1973, just before his death, Carl Backman, longtime manager of the Western Department in Chicago for the Redpath Bureau, arranged to transfer additional Chautauqua and lyceum materials to the Library, including talent circulars, photographs, publicity, correspondence, and additional copies of The Lyceum News, Program, and Talent magazines. Then, in the summer of 1973, Albert E. Moredock, a retired Westinghouse metallurgical engineer from Waynesburg, Pennsylvania, who had spent five summers as a crewman with Swarthmore Chautauqua, presented a large gathering of material in memory of Fred and Nora High. Frederick Perry High had been a Chautauqua lecturer and publicist. The Moredock Collection consists of expense account sheets, route sheets, programs, newsletters, talent circulars, magazines, and books, much of the material relating to the Swarthmore Chautauqua. Thus the Chautauqua collection has grown to be the largest manuscript collection in The University of Iowa Libraries. At a time when there is a good deal of scholarly interest in popular culture, this vast assemblage of material presents exceptional research opportunities.

23 For information on the Ellison-White Chautauqua System, see Victoria Case and Robert Ormond Case, We Called It Culture, The Story of Chautauqua (Garden City, New York: Doubleday \& Company, Inc., 1948). J. Roy Ellison extended Chautauqua into Canada and eventually into Australia and New Zealand. We Called It Culture is a popular and rather uncomplimentary treatment of circuit Chautauqua.

24 According to Bryan Horner, many of the old files of the Redpath-Kansas City office were destroyed when the main building of the old Kansas City Horner Conservatory was razed. 